\title{
THEORETICAL STUDY ON THE EXTRACTION OF ALKALINE EARTH SALTS BY 18-CROWN-6: ROLES OF COUNTERIONS, SOLVENT TYPES AND EXTRACTION TEMPERATURES
}

\author{
Saprizal Hadisaputra ${ }^{1,3}$, Lorenz R Canaval ${ }^{2}$, Harno Dwi Pranowo ${ }^{3, *}$, and Ria Armunanto ${ }^{3}$ \\ ${ }^{1}$ Chemistry Education Division, Faculty of Teacher Training and Science Education, Universitas Mataram \\ Jl. Majapahit 62, Mataram 83251 Indonesia \\ ${ }^{2}$ Division of Theoretical Chemistry, Institute of General, Inorganic and Theoretical Chemistry \\ University of Innsbruck, Innsbruck, Austria \\ ${ }^{3}$ Austrian Indonesian Centre for Computational Chemistry, Universitas Gadjah Mada \\ Sekip Utara, Yogyakarta 55281 Indonesia
}

Received April 2, 2014; Accepted May 30, 2014

\begin{abstract}
The roles of counterions, solvent types and extraction temperatures on the selectivity of 18-crown-6 (L) toward alkaline earth salts $\mathrm{MX}_{2}\left(\mathrm{M}=\mathrm{Ca}, \mathrm{Sr}, \mathrm{Ba} ; \mathrm{X}=\mathrm{Cl}, \mathrm{NO}_{3}^{-}\right)$have been studied by density functional method at $\mathrm{B} 3 \mathrm{LYP}$ level of theory in gas and solvent phase. In gas phase, the chloride anion $\mathrm{Cl}$ is the preference counterion than nitrate anion $\mathrm{NO}_{3}^{-}$. This result is confirmed by the interaction energies, the second order interaction energies, charge transfers, energy difference between HOMO-LUMO and electrostatic potential maps. The presence of solvent reversed the gas phase trend. It is found that $\mathrm{NO}_{3}{ }^{-}$is the preference counterion in solvent phase. The calculated free energies demonstrate that the solvent types strongly change the strength of the complex formation. The free energies are exothermic in polar solvent while for the non polar solvent the free energies are endothermic. As the temperature changes the free energies also vary where the higher the temperatures the lower the free energy values. The calculated free energies are correlated well with the experimental stability constants. This theoretical study would have a strong contribution in planning the experimental conditions in terms of the preference counterions, solvent types and optimum extraction temperatures.
\end{abstract}

Keywords: DFT; crown ether; counterion; solvent; temperature

\section{ABSTRAK}

Pengaruh anion penyeimbang, jenis pelarut dan temperatur pada selektivitas 18-mahkota-6 terhadap garam logam alkali tanah $\mathrm{MX}_{2}\left(\mathrm{M}=\mathrm{Ca}, \mathrm{Sr}, \mathrm{Ba} ; \mathrm{X}=\mathrm{Cr}, \mathrm{NO}_{3}{ }^{-}\right)$telah dipelajari menggunakan metode teori kerapatan funsional pada tingkatan teori B3LYP pada fasa gas dan larutan. Pada fasa gas, anion klorida (Cl) lebih disukai dibandingkan anion $\mathrm{NO}_{3}{ }^{-}$. Hasil ini sesuai dengan energi interaksi, energi interaksi orde kedua, transfer muatan, energi HOMO-LUMO dan peta potensial elektrostatik. Kehadiran pelarut membalikkan tren pada fase gas. Hal ini ditemukan bahwa $\mathrm{NO}_{3}^{-}$lebih disukai dibandingkan $\mathrm{Cl}$ pada fasa larutan. Energi bebas fasa larutan menunjukkan bahwa jenis pelarut mengubah kekuatan interaksi kompleks yang terbentuk. Pelarut polar menyebabkan energi bebas bersifat eksotermik sedangkan pelarut non polar menyebabkan energi bebas bersifat endotermik. Perubahan temperatur juga menyebabkan perubahan energi bebas dimana semakin tinggi temperatur maka semakin rendah energi bebas kompleks. Hasil energi bebas teoritis memiliki korelasi yang baik dengan data eksperimental. Penelitian teoritis ini memiliki konstribusi dalam mendesain eksperimental dari segi pilihan anion penyeimbang, jenis pelarut dan kondisi temperatur yang optimal.

Kata Kunci: DFT; eter mahkota; anion; pelarut; temperatur

\section{INTRODUCTION}

Crown ether is well known as the highly selective separation agents [1-2]. Selectivity of crown ether not only sensitive toward cation diameter, macrocycle cavity size, donor atoms, electron donating and withdrawing group substitution but also the complementary counterion, solvent types and extraction temperatures. In the case of the charged metal complex and the counterion exist mainly in the same cage solvent, the counterion effects will be observed [3]. The EXAFS experiment showed that even in highly solvated

* Corresponding author

Email address : harnodp@ugm.ac.id 
environment, counterion still has influence. It is demonstrated by the strontium coordination environment (10 coordination numbers) does not change in $\mathrm{Sr}\left(\mathrm{NO}_{3}\right)_{2}-$ $18 \mathrm{C} 6$ and $\mathrm{Sr}\left(\mathrm{NO}_{3}\right)_{2}$-DC18C6 when they are prepared by extracting $\mathrm{Sr}\left(\mathrm{NO}_{3}\right)_{2}$ salt from highly solvated aqueous solution and then extracted into 1-octanol [4].

Solvent also controls the selectivity of crown ether toward metal ions. For instant, in the solvent phase the complex formation of 18-crown-6 toward alkaline earth ions demonstrated that the order of the selectivity was $\mathrm{Ba}^{2+}>\mathrm{Sr}^{2+}>\mathrm{Ca}^{2+}>\mathrm{Mg}^{2+}$ [5]. However, in the gas phase studies the order of the selectivity was turned out to be opposite $\mathrm{Mg}^{2+}>\mathrm{Ca}^{2+}>\mathrm{Sr}^{2+}>\mathrm{Ba}^{2+}$ [6-7]. This discrepancy between solvent and gas phase indicated that solvent is strongly influence the binding selectivity of crown ether. The extraction temperature also plays important role in metal crown ether interaction. Several experimental [7-9] have been taken to study the influence of temperatures on stability constant of metal crown ether complexes. It is reported that as the extraction temperatures increase, the stability constant of crown ether alkaline earth complexes reduce. Thus, theoretical study on the effect of counterion, solvent types and extraction temperatures in the complexation of alkaline earth with crown ether is crucial from practical application point of view.

The theoretical investigation has been used extensively to study the selective capture of metal ions by crown ether at various level of electronic structure method. Theoretical studies have been performed on the effect of cavity size, donor atoms, electron donating and withdrawing group substitution on the metal ion-crown ether interaction [10-15]. However, very few theoretical studies have attempted to study the role of counterion, solvent types and extraction temperatures on the alkaline earth crown ether complexes. Recently, the DFT $\mathrm{B} 3 \mathrm{LYP} / 6-31+\mathrm{G}(\mathrm{d})$ level of theory have also been performed on ion-pair receptor of calixarene derivative and its interactions with the halide anions $\mathrm{F}^{-}, \mathrm{Cl}^{-}$, and $\mathrm{Br}^{-}$ and the cesium halides $\mathrm{CsF}, \mathrm{CsCl}$, and $\mathrm{CsBr}$ [16]. Inclusion of $\mathrm{Mg}^{2+}, \mathrm{Ca}^{2+}, \mathrm{Sr}^{2+}, \mathrm{Ba}^{2+}$ within the cavity of dibenzo-18-crown-6 has been reported using B3LYP/LanL2DZ and $6-31+G(d)$ level of theory in gas and solvent phase [17]. The extraction properties of 12-crown-4 derivates toward $\mathrm{Li}^{+}$with $\mathrm{Cl}^{-}$as counterion in biphasic solvent phase has been studied at B3LYP and MP2/6-311+G(d,p) level of theory [18]. The extraction of $\mathrm{Sr}\left(\mathrm{NO}_{3}\right)_{2}$ salt with 18-membered crown ethers in biphasic solvent has been studied using DFT method at B3LYP level of theory using SDD and DZP basis sets. The extraction energies from biphasic systems showed linear trend with the experimental stability constant [19].

In the current work, we use density functional theory (DFT) to study the effect of counterions, extraction temperatures and solvent types on the structural parameter, energy and thermodynamics of $\mathrm{MX}_{2}\left(\mathrm{M}=\mathrm{Ca}, \mathrm{Sr}, \mathrm{Ba} ; \mathrm{X}=\mathrm{Cl}^{-}\right.$and $\left.\mathrm{NO}_{3}{ }^{-}\right)$within the cavity of 18-crown-6 (L) in gas and solvent phase. In this study, chloride anion $\mathrm{Cl}^{-}$and nitrate anion $\mathrm{NO}_{3}{ }^{-}$are chosen as they are commonly presence in solvent extraction. Furthermore, different strength of steric hindrance due to monodentate and bidentate binding mode from chloride and nitrate anions is interested for comparison. In solvent phase, continuum solvation model is implemented due to its flexibility and efficiency compared to explicit solvation model. Despite the extensive uses of continuum solvation model, only few studied have been conducted on the complexation of crown ethers in solution.

\section{COMPUTATIONAL METHOD}

All calculations were based on approximate DFT in the hybrid B3LYP functional. All calculations reported here are performed using the Gaussian 03 package [20]. Geometry optimizations have been performed without any symmetry constraints. Optimized geometries are always verified as minima on the potential energy surface by calculating the harmonic vibration frequencies. Quasi-relativistic ECP with corresponding SDD basis set leaving 10 valence electrons was used for calcium, strontium and barium. For ligand atoms, DZP basis set was used. The basis set superposition errors (BSSE) was eliminated with the counterpoise (CP) method [21].

Solvent effects are included using the polarized continuum model (PCM) as implemented in the Gaussian code. The dielectric constant for the water solvent was taken as 78.4 and other solvents were used as in Gaussian code. In employing PCM model, the single-point calculations on gas-phase geometries are sufficient for energetic. Structure re-optimization in the presence of the solvent was found to have a minor influence on energetic [22]. The non-electrostatic contributions are neglected in this study due to their minor influences on temperature variations. All Gibbs free energy calculations in solvent phase were corrected toward standard states from the gas phase to the condensed phase. This correction term is numerically equivalent to $\pm 1.89 \mathrm{kcal} \mathrm{mol}^{-1}$ at $298.15 \mathrm{~K}$ [23-24] and for the other temperatures the correction terms are also applied with their values based on $-\mathrm{RT}$ In (1/22.47) equation.

\section{RESULT AND DISCUSSION}

\section{Geometrical Parameters}

The calculated geometrical structures of free 18-crown-6 $(\mathrm{L})$ and $M \mathrm{X}_{2} \mathrm{~L}$ complexes are presented in 
Table 1. Geometrical parameter (in $\AA$ ) of $M X_{2} L$ at $B 3 L Y P$ level of theory using combination SDD basis set correspond to small core ECP and DZP basis set

\begin{tabular}{|c|c|c|c|c|c|c|c|c|c|}
\hline Complexes & $\begin{array}{c}\text { Minimum } \\
\mathrm{M}-\mathrm{O}\end{array}$ & $\begin{array}{c}\text { Maximum } \\
\mathrm{M}-\mathrm{O}\end{array}$ & \multicolumn{2}{|c|}{$M-X 1$} & \multicolumn{2}{|c|}{ MX2 } & $\mathrm{C}-\mathrm{C}$ & $\mathrm{C}-\mathrm{O}$ & $\begin{array}{c}\text { Cavity size } \\
\mathrm{O}-\mathrm{O}\end{array}$ \\
\hline $\mathbf{L}(18 \mathrm{C} 6)$ & & & & & & & $\begin{array}{l}1.520 \\
1.511^{b}\end{array}$ & $\begin{array}{l}1.415 \\
1.418^{b}\end{array}$ & $\begin{array}{l}5.846 \\
5.67 \pm 03^{\mathrm{c}}\end{array}$ \\
\hline $\mathrm{CaCl}_{2} \mathbf{L}$ & 2.622 & 2.703 & 2.642 & & 2.642 & & 1.516 & 1.422 & 5.245 \\
\hline $\mathrm{SrCl}_{2} \mathrm{~L}$ & 2.755 & 2.761 & 2.802 & & 2.802 & & 1.522 & 1.426 & 5.346 \\
\hline $\mathrm{BaCl}_{2} \mathrm{~L}$ & 2.752 & 2.854 & 2.956 & & 2.957 & & 1.526 & 1.431 & 5.505 \\
\hline $\mathrm{Ca}\left(\mathrm{NO}_{3}\right)_{2} \mathrm{~L}$ & $\begin{array}{l}2.614 \\
2.560^{a}\end{array}$ & $\begin{array}{l}2.788 \\
2.673^{a}\end{array}$ & 2.437 & $\begin{array}{l}2.460 \\
2.501^{a}\end{array}$ & 2.495 & $\begin{array}{l}2.496 \\
2.501^{a}\end{array}$ & $\begin{array}{l}1.523 \\
1.459^{a}\end{array}$ & $\begin{array}{l}1.420 \\
1.416^{a}\end{array}$ & $\begin{array}{l}5.187 \\
5.198^{\mathrm{a}}\end{array}$ \\
\hline $\mathrm{Sr}\left(\mathrm{NO}_{3}\right)_{2} \mathbf{L}$ & 2.718 & 2.805 & 2.594 & 2.595 & 2.663 & 2.664 & 1.524 & 1.423 & 5.282 \\
\hline $\mathrm{Ba}\left(\mathrm{NO}_{3}\right)_{2} \mathrm{~L}$ & 2.824 & 2.891 & 2.755 & 2.756 & 2.860 & 2.862 & 1.527 & 1.429 & 5.399 \\
\hline
\end{tabular}

Xray data $\mathrm{Ca}\left(\mathrm{NO}_{3}\right)_{2}-18 \mathrm{C} 6$, ref [25] b. experiment data, ref [26]; c. experimental cavity size $\mathrm{D}_{3 \mathrm{~d}}$ conformation [27]

Table 2. Calculated interaction energies $\Delta \mathrm{E}\left(\mathrm{kcal}^{\mathrm{mol}} \mathrm{l}^{-1}\right)$, BSSE energies (kcal.mol $\left.{ }^{-1}\right)$, BSSE corrected interaction

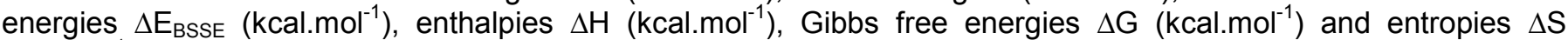
(cal.mol ${ }^{-1}$ ) in gas phase for the $\mathrm{MX}_{2} \mathrm{~L}$ complexes at $298.15 \mathrm{~K}$

\begin{tabular}{lrrrrrc}
\hline Complexes & $\Delta \mathrm{E}$ & $\mathrm{BSSE}$ & $\Delta \mathrm{E}_{\mathrm{BSSE}}$ & $\Delta \mathrm{H}$ & $\Delta \mathrm{G}$ & $\Delta \mathrm{S}$ \\
\hline $\mathrm{CaCl}_{2} \mathrm{~L}$ & -91.329 & 6.399 & -84.929 & -71.315 & -56.153 & -50.796 \\
$\mathrm{SrCl}_{2} \mathrm{~L}$ & -90.711 & 6.713 & -83.998 & -73.429 & -58.122 & -51.279 \\
$\mathrm{BaCl}_{2} \mathrm{~L}$ & -79.463 & 6.741 & -72.722 & -62.708 & -48.355 & -48.084 \\
$\mathrm{Ca}\left(\mathrm{NO}_{3}\right)_{2} \mathrm{~L}$ & -82.442 & 9.283 & -73.159 & -62.088 & -44.943 & -57.441 \\
$\mathrm{Sr}\left(\mathrm{NO}_{3}\right)_{2} \mathrm{~L}$ & -84.430 & 9.238 & -75.192 & -66.859 & -49.647 & -57.661 \\
$\mathrm{Ba}\left(\mathrm{NO}_{3}\right)_{2} \mathrm{~L}$ & -78.089 & 9.148 & -68.940 & -60.655 & -48.589 & -40.423 \\
\hline
\end{tabular}

Table 1 together with corresponding experimental geometrical parameters. It can be seen that the calculated bond lengths are in a good agreement with the experimental data. Though the B3LYP with combination SDD and DZP basis set produces systematically longer bond lengths than the corresponding experimental values, the differences in bond lengths is relatively small and all calculated data are within the range of experimental values. The selective minimum and maximum bond lengths of $\mathrm{M}-\mathrm{O}$ in $\mathrm{MCl}_{2} \mathrm{~L}$ complexes are slightly shorter than that of $\mathrm{M}-\mathrm{O}$ distances in $\mathrm{M}\left(\mathrm{NO}_{3}\right)_{2} \mathrm{~L}$. Bond lengths of $\mathrm{M}-\mathrm{O}$ in $\mathrm{MCl}_{2} \mathrm{~L}$ are ranged from 2.622-2.854 $\AA$ while for $M\left(N_{3}\right)_{2} \mathrm{~L}$ complexes the bond lengths are 2.614-2.891 $\AA$. These $\mathrm{M}-\mathrm{O}$ bonds are approximately $0.1 \AA$ longer than the $\mathrm{M}-\mathrm{O}$ bond from the free counterions complexes from previous study [6]. The longer distance of $\mathrm{M}-\mathrm{O}$ bond in $\mathrm{MX}_{2} \mathrm{~L}$ complexes compared with free counterion complexes can be explained by the increased steric hindrance due to the presence of counterions in the first coordination sphere of the complexes. The calculated $\mathrm{C}-\mathrm{C}$ and $\mathrm{C}-\mathrm{O}$ bond distances only $0.09 \AA$ and $0.03 \AA$ differences than the experimental values [25]. The calculated C-C $(1.516-1.527 \AA)$ and C-O (1.422-1.429 $\AA$ ) bonds after complexation with metal salts is slightly lengthened compared with the calculated C-C (1.520 $\AA$ ) and C-O $(1.415 \AA$ ) bonds from free metal 18-crown- 6 .

Another important geometrical parameter of crown ethers is the size of their cavity. The binding selectivity of crown ether with metal ions is determined by the diameter size of metal ions and the crown ether cavity size. The cavity size of crown ether is calculated by the distances between the opposite of oxygen atoms. The calculated and experimental values of cavity size are also given in Table 1 . The calculated cavity size shows that the cavity size of free 18-crown-6 is larger than the results of experiments by $0.17 \AA$ but still within the range of experiment data. Changes in the size of the free crown ether cavity are evidently occurred in the presence of metal in the cavity of L. Crown ether cavity size is reduced about $7.49 \%, 5.71 \%, 2.91 \%$ for $\mathrm{CaCl}_{2} \mathrm{~L}$, $\mathrm{SrCl}_{2} \mathrm{~L}$ and $\mathrm{BaCl}_{2} \mathrm{~L}$ respectively and $8.51 \%, 6.84 \%$, $4.77 \%$ for $\mathrm{Ca}\left(\mathrm{NO}_{3}\right)_{2} \mathrm{~L}, \mathrm{Sr}\left(\mathrm{NO}_{3}\right)_{2} \mathrm{~L}$ and $\mathrm{Ba}\left(\mathrm{NO}_{3}\right)_{2} \mathrm{~L}$ as a result of strong electrostatic interaction by the metal with the dipole offered by the donor crown ligand. Comparing cavity size as the consequence of the presence of $\mathrm{Cl}^{-}$and $\mathrm{NO}_{3}{ }^{-}$, it demonstrates that the presence of $\mathrm{Cl}^{-}$leads to smaller cavity size than the cavity size when $\mathrm{NO}_{3}^{-}$as counterion. This trend possibly due to $\mathrm{NO}_{3}^{-}$has stronger steric hindrance compared to $\mathrm{Cl}^{-}$which only coordinates in monodentate binding mode to metal ions.

The crystal structure of $\mathrm{Ca}\left(\mathrm{NO}_{3}\right)_{2} \mathrm{~L}$ has been determined by Polyanskaya [25] and it shows the nitrate anions lie in the sandwich position (top and below) on either side of the crown ether cavity. The other complexes have closely similar structure to $\mathrm{Ca}\left(\mathrm{NO}_{3}\right)_{2} \mathrm{~L}$ complex. The optimized structure of $\mathrm{Ca}\left(\mathrm{NO}_{3}\right)_{2} \mathrm{~L}$ and other complexes are displayed in Fig. 1 . The calculated $M-X$ bond distance is gradually increased as the diameter of metal increase and follows the order of $\mathrm{Ca}-\mathrm{X}<\mathrm{Sr}-\mathrm{X}<\mathrm{Ba}-\mathrm{X}$. The maximum 

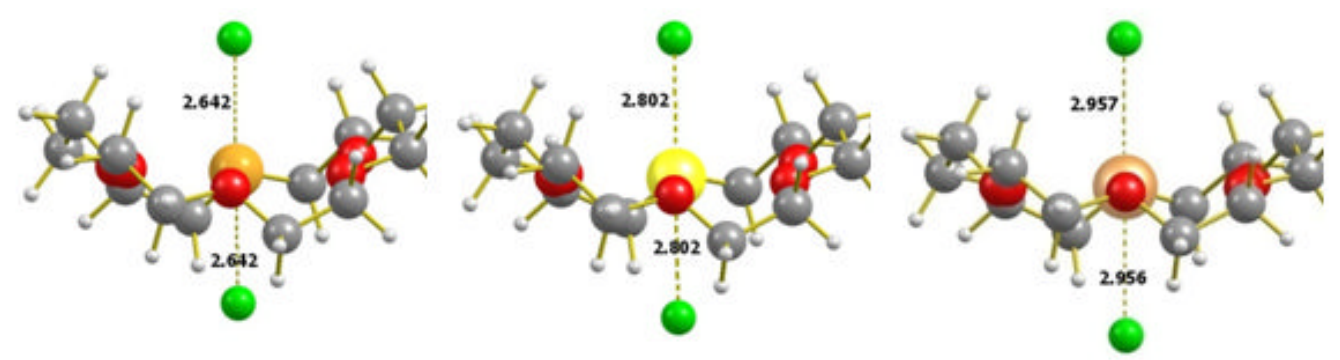

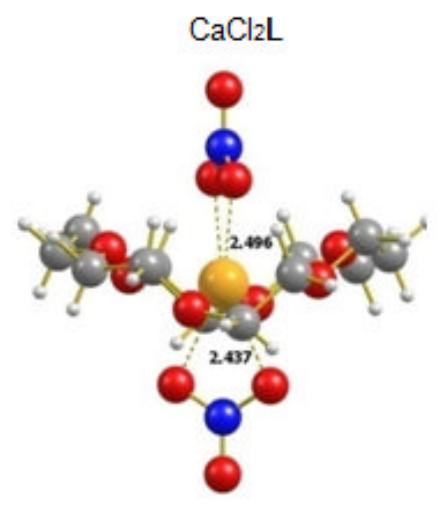

$\mathrm{Ca}\left(\mathrm{NO}_{3}\right)_{2} \mathrm{~L}$

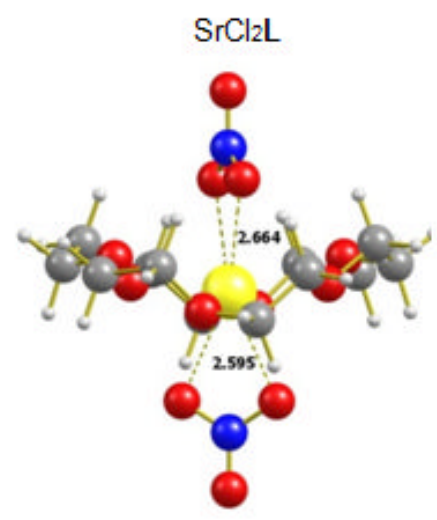

$\mathrm{Sr}\left(\mathrm{NO}_{3}\right)_{2} \mathrm{~L}$

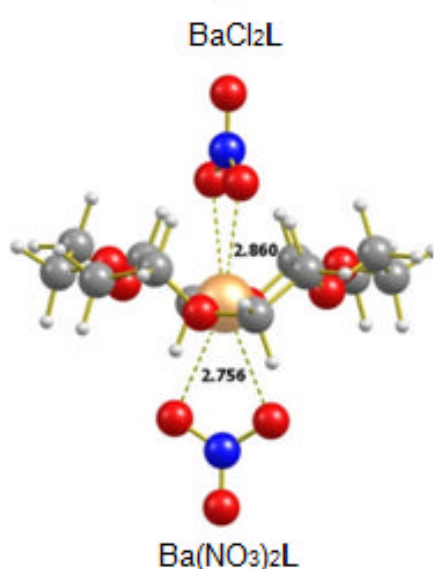

$\mathrm{Ba}\left(\mathrm{NO}_{3}\right)_{2} \mathrm{~L}$

Fig 1. The optimized structure of $\mathrm{MX}_{2} \mathrm{~L}\left(\mathrm{X}=\mathrm{Cl}^{-}\right.$and $\left.\mathrm{NO}_{3}{ }^{-}\right)$complexes at $\mathrm{B} 3 \mathrm{LYP}$ level of theory using combination SDD and DZP basis sets at $298.15 \mathrm{~K}$

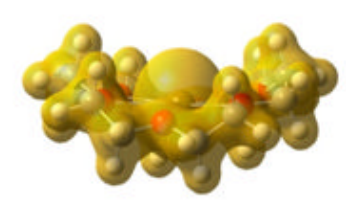

A

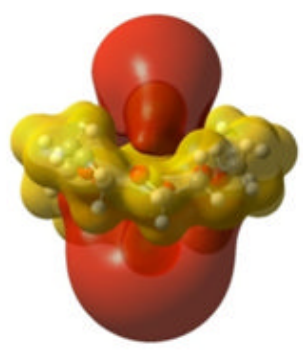

$\mathrm{B}$

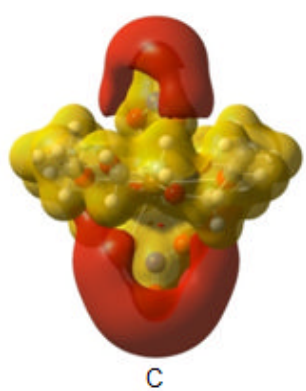

Fig 2. Visualization of electrostatic potential map. A) $\mathrm{Ca}^{2+}-\mathrm{L}$ complex with no counterions; $\mathrm{B}$ ) with $\mathrm{Cl}^{-}$as counterion on the complex; C) with $\mathrm{NO}_{3}{ }^{-}$as counterion on the complex. Red indicates electron rich regions of the molecules

$\mathrm{M}-\mathrm{Cl}$ bond was found in $\mathrm{Ba}-\mathrm{Cl}(2.957 \AA)$ and the lowest bond was $\mathrm{Ca}-\mathrm{Cl}(2.642 \AA)$. Similar trend also found for $\mathrm{M}-\mathrm{O}_{\mathrm{NO} 3}$ distances where the maximum $\mathrm{M}-\mathrm{O}_{\mathrm{NO} 3}$ was found in $\mathrm{Ba}^{-} \mathrm{O}_{\mathrm{NO} 3}(2.862 \AA)$ and the lowest bond was found in $\mathrm{Ca}-\mathrm{O}_{\mathrm{NO} 3}(2.496 \AA)$. The trend in bond length distances can be used as the preliminary prediction of the strength of interaction between the metal ions and crown ethers. It can be seen that the shortest bond lengths for $\mathrm{M}-\mathrm{O}$ and $\mathrm{M}-\mathrm{X}$ bonds are identified for $\mathrm{CaCl}_{2} \mathrm{~L}$ complex. Thus, it is predicted that the strongest interaction would be the interaction between $\mathrm{CaCl}_{2}$ and $\mathrm{L}$ in gas phase.

\section{Energy and Thermodynamics Parameters}

Generally, the interaction energy is related to the stability of the complexes. The interaction energies for the metal ion (M) and crown ether (CE) complexes were calculated as the energy difference between the complexes and their monomer. The interaction energies were also corrected for the undesirable effects of basis set superposition error (BSSE) using the counterpoise method. For the interaction in the system involved, the interaction energy can be expressed as follows:

$\Delta \mathrm{E}=\mathrm{E}_{\mathrm{M} \times 2-\mathrm{CE}}-\left(\mathrm{E}_{\mathrm{MX2}}+\mathrm{E}_{\mathrm{CE}}\right)$

Here, $E_{M X 2-C E}$ was the complex energy, $E_{M X 2}$ the energy of metal salts and $E_{C E}$ the energy of crown ether. The calculated interaction energies for the complexes in the gas phase with the absence of solvent molecule are listed in Table 2.

As predicted, the gas phase selectivity for the same counterion decrease as the size of metal cations increase from $\mathrm{CaX}{ }_{2} \mathrm{~L}$ to $\mathrm{BaX}_{2} \mathrm{~L}$, except for $\mathrm{Ca}\left(\mathrm{NO}_{3}\right)_{2} \mathrm{~L}$ 
Table 3. The maximum second-order interaction energies $E_{2}$ (kcal.mol ${ }^{-1}$ ) of counterion contributions and the energy gap $(\Delta \varepsilon)$ between $\mathrm{E}_{\text {HOMO }}$ and $\mathrm{E}_{\mathrm{LUMO}}(\mathrm{eV})$.

\begin{tabular}{|c|c|c|c|c|c|c|c|}
\hline \multirow{2}{*}{ Complexes } & \multicolumn{2}{|c|}{ Maximum Donation NBO } & \multirow{2}{*}{$E_{2}$} & \multicolumn{2}{|c|}{ Back-Donation NBO } & \multirow{2}{*}{$E_{2}^{*}$} & \multirow{2}{*}{$\Delta \varepsilon$} \\
\hline & Donor & Acceptor & & Donor & Acceptor & & \\
\hline $\mathrm{CaCl}_{2} \mathrm{~L}$ & LP(4)Cl45 & $\mathrm{LP}^{*}(1) \mathrm{Ca} 43$ & 31.92 & $\mathrm{LP}^{*}(1) \mathrm{Ca} 43$ & $\mathrm{RY}^{*}(4) \mathrm{Cl} 45$ & 6.11 & 1.04 \\
\hline $\mathrm{SrCl}_{2} \mathrm{~L}$ & LP(4)Cl45 & $\mathrm{LP}^{*}(1) \mathrm{Sr} 43$ & 27.12 & $\mathrm{LP}^{*}(1) \mathrm{Sr} 43$ & $\mathrm{RY}^{*}(4) \mathrm{Cl} 45$ & 4.56 & 1.01 \\
\hline $\mathrm{BaCl}_{2} \mathrm{~L}$ & LP(4)Cl45 & $\mathrm{LP}^{*}(1) \mathrm{Ba} 43$ & 18.09 & $\mathrm{LP}^{\star}(1) \mathrm{Ba} 43$ & $\mathrm{RY}^{*}(4) \mathrm{Cl} 45$ & 0.07 & 0.89 \\
\hline $\mathrm{Ca}\left(\mathrm{NO}_{3}\right)_{2} \mathrm{~L}$ & LP(1)O8 & $\mathrm{LP}^{*}(1) \mathrm{Ca} 51$ & 8.91 & $\mathrm{LP}^{*}(1) \mathrm{Ca} 51$ & $\mathrm{RY}^{*}(2) \mathrm{O} 8$ & 4.05 & 0.87 \\
\hline $\mathrm{Sr}\left(\mathrm{NO}_{3}\right)_{2} \mathbf{L}$ & LP(1)O8 & $\mathrm{LP}^{*}(1) \mathrm{Sr} 51$ & 7.46 & $\mathrm{LP}^{*}(1) \mathrm{Sr} 51$ & $R Y^{*}(2) \mathrm{O} 8$ & 2.5 & 0.85 \\
\hline $\mathrm{Ba}\left(\mathrm{NO}_{3}\right)_{2} \mathrm{~L}$ & LP(1)08 & $\mathrm{LP}^{*}(1) \mathrm{Ba} 51$ & 4.51 & less tha & rreshold & & 0.84 \\
\hline
\end{tabular}

Table 4. The maximum second-order interaction energies $\mathrm{E}_{2}\left(\mathrm{kcal}^{\mathrm{mol}}{ }^{-1}\right)$ from crown ether oxygen atoms

\begin{tabular}{|c|c|c|c|c|c|c|}
\hline \multirow{2}{*}{ Complexes } & \multicolumn{2}{|c|}{ Maximum Donation NBO } & \multirow{2}{*}{$E_{2}$} & \multicolumn{2}{|c|}{ Back-Donation NBO } & \multirow{2}{*}{$E_{2}^{*}$} \\
\hline & Donor & Acceptor & & Donor & Acceptor & \\
\hline $\mathrm{CaCl}_{2} \mathrm{~L}$ & LP(1)O41 & $\mathrm{LP}^{*}(1) \mathrm{Ca} 43$ & 6.03 & $\mathrm{LP}^{*}(1) \mathrm{Ca} 43$ & $\mathrm{RY}^{*}(2) \mathrm{O} 41$ & 6.23 \\
\hline $\mathrm{SrCl}_{2} \mathrm{~L}$ & LP(1)O38 & $\mathrm{LP}^{*}(1) \mathrm{Sr} 43$ & 5.27 & $\mathrm{LP}^{*}(1) \mathrm{Sr} 43$ & $\mathrm{RY}^{*}(2) \mathrm{O} 38$ & 5.86 \\
\hline $\mathrm{BaCl}_{2} \mathbf{L}$ & LP(1)O38 & LP*(1)Ba43 & 3.64 & less tha & reshold & \\
\hline $\mathrm{Ca}\left(\mathrm{NO}_{3}\right)_{2} \mathrm{~L}$ & $\mathrm{LP}(1) \mathrm{O} 2$ & $\mathrm{LP}^{*}(1) \mathrm{Ca} 51$ & 5.23 & $\mathrm{LP}^{*}(1) \mathrm{Ca} 51$ & $\mathrm{RY}^{\star}(2) \mathrm{O} 2$ & 8.86 \\
\hline $\mathrm{Sr}\left(\mathrm{NO}_{3}\right)_{2} \mathrm{~L}$ & LP(1)O2 & $\mathrm{LP}^{*}(1) \mathrm{Sr} 51$ & 4.40 & $\mathrm{LP}^{*}(1) \operatorname{Sr} 51$ & $R Y^{*}(2) \mathrm{O} 2$ & 5.38 \\
\hline $\mathrm{Ba}\left(\mathrm{NO}_{3}\right)_{2} \mathrm{~L}$ & LP(1)O4 & $\mathrm{LP}^{*}(1) \mathrm{Ba} 51$ & 3.08 & less tha & reshold & \\
\hline
\end{tabular}

and $\mathrm{Sr}\left(\mathrm{NO}_{3}\right)_{2} \mathrm{~L}$. The BSSE corrected interaction energies follow the order $\mathrm{CaCl}_{2} \mathrm{~L}>\mathrm{SrCl}_{2} \mathrm{~L}>\mathrm{Sr}\left(\mathrm{NO}_{3}\right)_{2} \mathrm{~L}>$ $\mathrm{Ca}\left(\mathrm{NO}_{3}\right)_{2} \mathrm{~L}>\mathrm{BaCl}_{2} \mathrm{~L}>\mathrm{Ba}\left(\mathrm{NO}_{3}\right)_{2} \mathrm{~L}$. The inconsistency of $\mathrm{Sr}\left(\mathrm{NO}_{3}\right)_{2} \mathrm{~L}$ and $\mathrm{Ca}\left(\mathrm{NO}_{3}\right)_{2} \mathrm{~L}$ complexes from the best fit concept between metal diameter and cavity size indicates that it is not the only factors that determine the strength of interaction between $L$ and alkaline earth salts. Thus, in this context the presence of counterion has the role to change the binding selectivity for the complexes. The $\mathrm{Cl}^{-}$counterions produce higher interaction energies than that of $\mathrm{NO}_{3}{ }^{-}$counterion. It can be seen from the interaction energy for $\mathrm{CaCl}_{2} \mathrm{~L}$ $\left(-84.93 \mathrm{kcal}^{\mathrm{mol}}{ }^{-1}\right)$ is $10 \mathrm{kcal}^{\mathrm{mol}}{ }^{-1}$ higher than the interaction energy of $\mathrm{Ca}\left(\mathrm{NO}_{3}\right)_{2} \mathrm{~L}\left(-73.16 \mathrm{kcal}^{\mathrm{mol}}{ }^{-1}\right)$. This trend is also followed by $\mathrm{SrCl}_{2} \mathrm{~L}$ and $\mathrm{BaCl}_{2} \mathrm{~L}$ complexes $\left(-83.99\right.$ and $-72.72 \mathrm{kcal}^{\left.-\mathrm{mol}^{-1}\right)}$ with interaction energies are $10 \mathrm{kcal}^{\mathrm{mol}}{ }^{-1}$ and $9 \mathrm{kcal}^{\mathrm{mol}}{ }^{-1}$ higher than the interaction energies of $\mathrm{Sr}\left(\mathrm{NO}_{3}\right)_{2} \mathrm{~L}$ and $\mathrm{Ba}\left(\mathrm{NO}_{3}\right)_{2} \mathrm{~L}$ $\left(-73.97 \mathrm{kcal}^{\mathrm{mol}} \mathrm{m}^{-1}\right.$ and $\left.-68.94 \mathrm{kcal}^{\mathrm{mol}}{ }^{-1}\right)$. The enthalpies $(\Delta \mathrm{H})$ and free energies $(\Delta \mathrm{G})$ of reaction follow the interaction energy trends. The $\Delta \mathrm{H}$ and $\Delta \mathrm{G}$ of reactions are exothermic $\left(-71.32 \mathrm{kcal}^{\mathrm{mol}}{ }^{-1}\right.$ to $\left.-48.59 \mathrm{kcal}^{\mathrm{mol}}{ }^{-1}\right)$ means in gas phase metal salts interact strongly with crown ether.

\section{Natural Bond Orbital Analysis}

For further study on the effect of counterions, the second order interaction energies $\left(E_{2}\right)$ based on the Natural Bond Orbital (NBO) analysis were also calculated. $E_{2}$ corresponds to the intensity of change transfer interaction between Lewis donor and non-Lewis acceptor NBO. For each donor NBO (i) and acceptor
NBO $(j), E^{2}$ associated with $i \rightarrow j$ delocalization can be estimated as follows:

$$
E_{2}=\Delta E_{i j}=q_{i} \frac{F^{2}(i, j)}{\varepsilon_{i}-\varepsilon_{j}}
$$

Here, $q_{i}$ is the donor orbital occupancy, $\varepsilon_{i}, \varepsilon_{j}$ are diagonal elements (orbital energies) and $F_{(i, j)}$ are the off diagonal elements of NBO Fox matrix.

The $\mathrm{E}_{2}$ obtained from NBO analysis are shown in Table 3 . It is clearly indicated that the maximum donation and the maximum back-donation NBO contribute toward the binding selectivity. The lone pair electron (LP) of counterions and the antibond-lone pair electron $\left(L P^{*}\right)$ of the metal is mainly responsible for $E_{2}$ values. For instant in the case of $\mathrm{CaCl}_{2} \mathrm{~L}$ complex, the main contribution for $E_{2}$ is the orbital donor and acceptor from lone pair LP(4)Cl45 and antibond-lone pair LP*(1)Ca43 with $\mathrm{E}_{2}=31.92 \mathrm{kcal}^{*} \mathrm{~mol}^{-1}$ as shown in Table 3. As compensated, the back donation is produced by the antibond-lone pair electron $\mathrm{LP}^{*}(1) \mathrm{Ca} 43$ and the center Rydberg $\mathrm{RY}^{*}(4) \mathrm{Cl} 45$ with $\mathrm{E}_{2}{ }^{*}=6.11 \mathrm{kcal} \cdot \mathrm{mol}^{-1}$. The maximum values of $\mathrm{E}_{2}$ from counterion contribute higher toward complex stability than the maximum $E_{2}$ values from crown ether oxygen atoms (Table 4). The maximum second order interaction energies $\mathrm{E}_{2}$ trend follow the order of $\mathrm{CaCl}_{2} \mathrm{~L}$

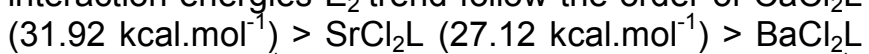
$\left(18.09 \mathrm{kcal}^{\mathrm{mol}}{ }^{-1}\right)$ and $\mathrm{Ca}\left(\mathrm{NO}_{3}\right)_{2} \mathrm{~L}\left(8.91 \mathrm{kcal}^{-1} \mathrm{~mol}^{-1}\right)$ $>\quad \mathrm{Sr}\left(\mathrm{NO}_{3}\right)_{2} \mathrm{~L}\left(7.46 \quad \mathrm{kcal} . \mathrm{mol}^{-1}\right)>\mathrm{Ba}\left(\mathrm{NO}_{3}\right)_{2} \mathrm{~L}$ $\left(4.51 \mathrm{kcal}^{\mathrm{mol}}{ }^{-1}\right)$. This trend have similar trend with the interaction energies, except for $\operatorname{Sr}\left(\mathrm{NO}_{3}\right)_{2} \mathrm{~L}$. Based on the $\mathrm{E}_{2} \mathrm{NBO}$ analysis results, it can be concluded that the maximum $E_{2}$ values confirms the counterions play significant role in the enhancement of the complex stability in gas phase. 
Table 5. Mulliken population analysis (MPA) charges $Q$ (a.u) of $L$ and selected complexes

\begin{tabular}{lcccccc}
\hline \multicolumn{1}{c}{ Complexes } & $\mathrm{Q}(\mathrm{M})$ & $\begin{array}{c}\text { Average } \\
\mathrm{Q}(\mathrm{O}) 18 \mathrm{C} 6\end{array}$ & $\mathrm{Q}(\mathrm{X} 1=\mathrm{Cl}, \mathrm{O})$ & $\mathrm{Q}(\mathrm{X} 2=\mathrm{Cl}, \mathrm{O})$ \\
\hline $\mathbf{L}(18-\mathrm{crown}-6)$ & & -0.263 & & & & \\
$\mathrm{CaCl}{ }_{2} \mathrm{~L}$ & 0.534 & -0.312 & -0.537 & & -0.538 & \\
$\mathrm{SrCl} \mathbf{L}$ & 0.575 & -0.322 & -0.564 & & -0.565 & \\
$\mathrm{BaCl}$ & 0.639 & -0.333 & -0.586 & -0.586 & \\
$\mathrm{Ca}\left(\mathrm{NO}_{3}\right)_{2} \mathrm{~L}$ & 0.785 & -0.303 & -0.414 & -0.414 & -0.400 & -0.400 \\
$\mathrm{Sr}\left(\mathrm{NO}_{3}\right)_{2} \mathbf{L}$ & 0.863 & -0.314 & -0.426 & -0.426 & -0.414 & -0.414 \\
$\mathrm{Ba}\left(\mathrm{NO}_{3}\right)_{2} \mathbf{L}$ & 0.972 & -0.330 & -0.433 & -0.433 & -0.427 & -0.427 \\
\hline
\end{tabular}

The HOMO-LUMO energy can be used for further explaining the role of counterion in metal crown ether complexes. A higher value of $\left(\mathrm{E}_{\text {номо }}\right)$ shows a tendency of the molecule to donate electrons to appropriate acceptor molecule of low empty molecular orbital energy. On the other hand, the energy of the lowest unoccupied molecular orbital ( $\mathrm{E}_{\text {LUMO }}$ ) indicates the ability of the molecule to accept electrons. Larger values of the energy difference, $\Delta \varepsilon$ between $\mathrm{E}_{\mathrm{LUMO}}-\mathrm{E}_{\mathrm{HOMO}}$, present low reactivity to a chemical species and hence more stable and lower values of the energy difference show higher reactivity means less stable. From Table 3 , the $\Delta \varepsilon$ of $\mathrm{CaCl}_{2} \mathrm{~L}>\mathrm{SrCl}_{2} \mathrm{~L}>\mathrm{BaCl}_{2} \mathrm{~L}$ have higher values than that of $\mathrm{Ca}\left(\mathrm{NO}_{3}\right)_{2} \mathrm{~L}>\mathrm{Sr}\left(\mathrm{NO}_{3}\right)_{2} \mathrm{~L}>\mathrm{Ba}\left(\mathrm{NO}_{3}\right)_{2} \mathrm{~L}$ which means that the complexes of $\mathrm{MCl}_{2} \mathrm{~L}$ have lower reactivity and hence they are more stable than $\mathrm{M}\left(\mathrm{NO}_{3}\right)_{2} \mathrm{~L}$ complexes. This again confirms that $\mathrm{Cl}^{-}$contributes more toward complex stability than the $\mathrm{NO}_{3}{ }^{-}$contribution in gas phase.

Looking at MPA charges (Table 5), one can see that the average negative charges of oxygen crown ether increase about $0.05 \mathrm{e}$ - from free 18-crown-6. The presence of metal salts increased $\delta^{+} \delta^{-}$polarization of $\mathrm{O}-\mathrm{C}$ bonds. The charges of oxygen in crown ether are closely similar means that the amount of the charge transfer contribution from these oxygen atoms is very much equal. In contrast, the oxygen atoms from $\mathrm{NO}_{3}{ }^{-}$is less negatively charges than the $\mathrm{Cl}^{-}$counterion which leads to a decreased of charge transfer from the counterion to the metal and in turn its increases charge on metal. This explains the possible reason for weaker ion-dipole interaction in complexes with $\mathrm{NO}_{3}^{-}$as counterion than the complexes with $\mathrm{Cl}^{-}$as counterion. This result indicated the simple charge-charge electrostatic interaction can be used to explain the trend in binding selectivity of 18 -crown-6. The MPA results have a good correlation with the interaction energies $(\Delta E)$, second order interaction energies $\left(E_{2}\right)$ and energy gab $(\Delta \varepsilon)$.

In order to study the electron distribution as the consequence of the presence of counterions, the maps of electrostatic potentials for $\mathrm{CaX}_{2} \mathrm{~L}$ complexes are displayed in Fig. 2. Electrostatic potential map can be used for indicating the electron rich or electron poor regions of the molecules [28]. Red color represents the large negative values of the potential which represent electron rich regions, while yellow indicates the large positive values of the potential represent electron poor regions. From Fig. $2 \mathrm{~A}$, it clearly shows that the surface of free counterion complex is dominated by positive values of potentials or electron poor regions. In the absent of counterion, the complex charges is dominated by the positive charge of metal ion that why the positive values of potential dominate the electrostatic potential map. The presence of counterions (Fig. 2B-C) changes the appearances of electrostatic potential maps. The electron rich regions of molecules concentrate in surrounding $\mathrm{Cl}^{-}$counterions and this area push deeply toward metal core when $\mathrm{Cl}^{-}$ acts as counterion. Similarly, for $\mathrm{Ca}\left(\mathrm{NO}_{3}\right)_{2} \mathrm{~L}$ complex, the electron rich regions of the molecule concentrate on $\mathrm{NO}_{3}{ }^{-}$, however, it less intent toward metal core. It is the possible reason for the $\mathrm{CaCl}_{2} \mathrm{~L}$ complexes has higher interaction energy in gas phase that that of $\mathrm{Ca}\left(\mathrm{NO}_{3}\right)_{2} \mathrm{~L}$ complexes.

\section{Solvent Phase}

The role of counterions, solvent types and extraction temperatures are studied further in solvent phase. Firstly, the effect of counterions in solvent phase was examined by computing the Gibbs free energies $(\Delta G)$ of $M X_{2} L$ complexes. As anticipated that there are numerical differences between the calculated and the experimental $\Delta G$ values [29-31] from the studied complexes about 10-15 kcal.mol ${ }^{-1}$. However, the qualitative agreement between the calculated and experimental $\Delta G$ values are readily clear from the selectivity of the 18-crown-6 toward $\mathrm{SrCl}_{2}$ relative to other $\mathrm{MX}_{2}$ in different solvents, define as $a_{\mathrm{SrCl} 2 / \mathrm{MX} 2}=\Delta \mathrm{G}_{\mathrm{MX} 2}-\Delta \mathrm{G}_{\mathrm{SrCl} 2}$. It shows a fine qualitative agreement between the calculated and the experimental $\Delta G$ values (Fig. 3).

Table 6 displays the calculated $\Delta G$ of $M X_{2} L$ at B3LYP level of theory and the experimental stability constants $\left(\log \mathrm{K}_{\mathrm{ML}}\right)$. The gas phase values of $\Delta \mathrm{G}$ are reduced in the solvent phase as the polar solvent molecules weaken the $\mathrm{M}-\mathrm{L}$ binding. It is exampled by the Gibbs free energy of $\mathrm{CaCl}_{2} \mathrm{~L}$ complex in gas phase is $-56.15 \mathrm{kcal} . \mathrm{mol}^{-1}$ and in solvent phase it is reduced to 
Table 6. Calculated Gibbs Free energies $\Delta \mathrm{G}$ (kcal.mol ${ }^{-1}$ ) and the experimental $\log \mathrm{K}_{\mathrm{ML}}$ values in solvent phase for the $\mathrm{MX}_{2} \mathrm{~L}$ complexes at $298 \mathrm{~K}$

\begin{tabular}{|c|c|c|}
\hline Complexes & $\begin{array}{c}\text { Calculated } \\
\Delta G\end{array}$ & $\begin{array}{c}\text { Experimental log } \\
\mathrm{K}_{\mathrm{ML}^{*}}{ }^{*}\end{array}$ \\
\hline $\mathrm{CaCl}_{2} \mathrm{~L}$ & -15.20 & $0.50 \pm 0.10$ \\
\hline $\mathrm{SrCl}_{2} \mathrm{~L}$ & -17.29 & $2.75 \pm 0.05$ \\
\hline $\mathrm{BaCl}_{2} \mathrm{~L}$ & -18.53 & $3.79 \pm 0.05$ \\
\hline $\mathrm{Ca}\left(\mathrm{NO}_{3}\right)_{2} \mathrm{~L}$ & -16.14 & $3.21 \pm 0.10$ \\
\hline $\mathrm{Sr}\left(\mathrm{NO}_{3}\right)_{2} \mathbf{L}$ & -18.39 & $3.41 \pm 0.08$ \\
\hline $\mathrm{Ba}\left(\mathrm{NO}_{3}\right)_{2} \mathrm{~L}$ & -19.01 & $4.02 \pm 0.04$ \\
\hline
\end{tabular}

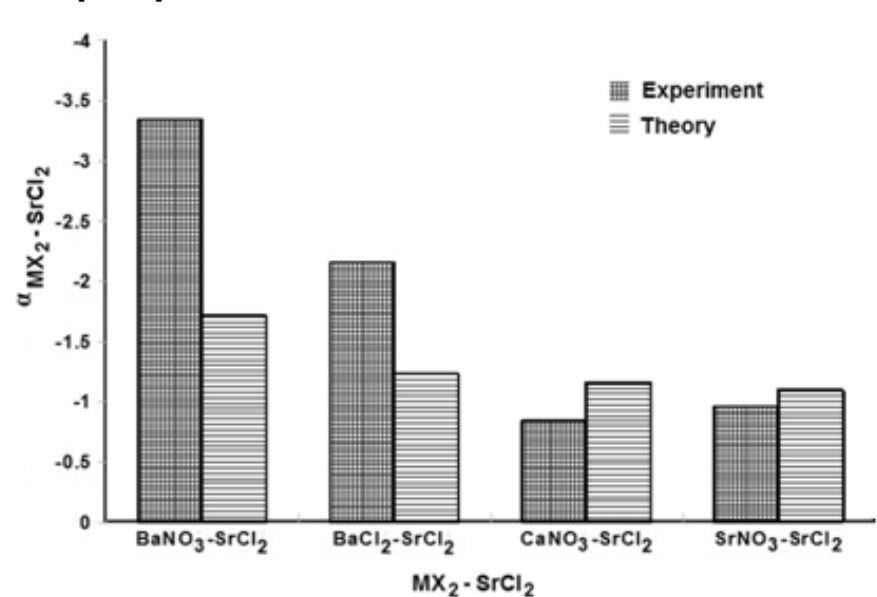

Fig 3. Calculated selectivity of $\mathrm{SrCl}_{2} \mathrm{~L}$ complexation with respect to other $M X_{2} L$ compared with experimental results from Ref [29-30]

$-15.20 \mathrm{kcal}^{\mathrm{mol}}{ }^{-1}$. Table 6 also shows that the change in the preferential selectivity of crown ether in solvent phase. It can be seen that the selectivity of $L$ in solvent phase is reversed the gas phase trend with the order $\mathrm{Ba}\left(\mathrm{NO}_{3}\right)_{2} \mathrm{~L}>\mathrm{BaCl}_{2} \mathrm{~L}>\mathrm{Sr}\left(\mathrm{NO}_{3}\right)_{2} \mathrm{~L}>\mathrm{SrCl}_{2} \mathrm{~L}>\mathrm{Ca}\left(\mathrm{NO}_{3}\right)_{2} \mathrm{~L}>$ $\mathrm{CaCl}_{2} \mathrm{~L}$. The exception from $\mathrm{Ca}\left(\mathrm{NO}_{3}\right)_{2} \mathrm{~L}$ and $\mathrm{Sr}\left(\mathrm{NO}_{3}\right)_{2} \mathrm{~L}$ complexes as shown in gas phase disappear. It shows that the best fit concept between diameter size and cavity of crown ether proposed earlier by Pedersen [1-2] gains its place in solvent phase. In general, the $\mathrm{BaX}_{2} \mathrm{~L}$ complex forms the most stable complex since the $\mathrm{Ba}^{2+}$ ionic size $(2.70 \AA)$ is very close to the size of the $L$ cavity $(2.76 \AA)$. The ionic size of the $\mathrm{Sr}^{2+}$ ion $(2.36 \AA)$ is relatively close to the cavity size of the $L$, but since the sizes of $\mathrm{Ca}^{2+}$ (ionic size $=2.00 \AA$ ) cations is smaller than the $\mathrm{L}$ cavity, its form less stable complexes with $\mathrm{L}$. Moreover, the steric hindrance is no longer a dominant factor in solvent phase. The monodentate binding mode from $\mathrm{Cl}^{-}$produces lower $\Delta \mathrm{G}$ values (-15.20 to $\left.-18.53 \mathrm{kcal}^{\mathrm{mol}}{ }^{-1}\right)$ compared with bidentate binding mode from $\mathrm{NO}_{3}^{-}$in which produces higher $\Delta G$ values $\left(-16.14\right.$ to $\left.-19.01 \mathrm{kcal}^{\mathrm{mol}}{ }^{-1}\right)$ for the same metal ion. Thus, simple conclusion can be drawn on the effect of different counterions in solvent phase where in

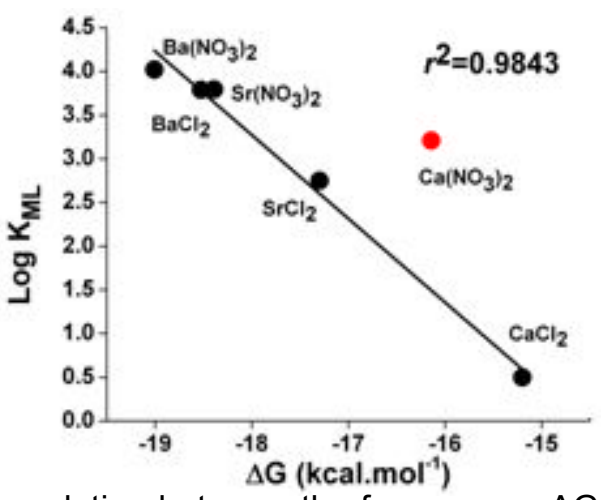

Fig 4. Correlation between the free energy $\Delta G$ and the stability constant (log $\mathrm{K}_{\mathrm{ML}}$ ) in $\mathrm{MX}_{2} \mathrm{~L}$ complexes, $r^{2}=0.9771$ (value for $\mathrm{Ca}\left(\mathrm{NO}_{3}\right)_{2} \mathrm{~L}$ excluded)

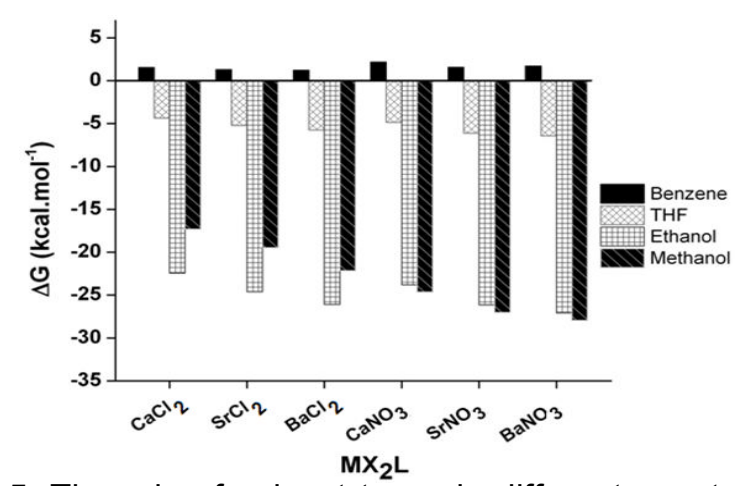

Fig 5. The role of solvent types in different counterion complexes

the same system (identical metal ion, solvent type and ligand $\mathrm{L}$ ), $\mathrm{NO}_{3}{ }^{-}$is a better choice of counterion that $\mathrm{Cl}^{-}$.

The correlation between the calculated $\Delta G$ values and experimental $\log \mathrm{K}_{\mathrm{ML}}$ in water at $298.15 \mathrm{~K}$ is presented in Fig. 4. With the exception of the value for $\mathrm{Ca}\left(\mathrm{NO}_{3}\right)_{2} \mathrm{~L}\left(\log \mathrm{K}_{\mathrm{ML}}=3.21 \pm 0.10\right)$, there is an excellent correlation between the calculated $\Delta G$ and the experimental $\log \mathrm{K}_{\mathrm{ML}}$ values with $r^{2}=0.9843$. The reason for the discrepancy with $\mathrm{Ca}\left(\mathrm{NO}_{3}\right)_{2} \mathrm{~L}$ is unclear.

\section{The Effect Solvent Types}

The role of solvent types on the selectivity of $18 \mathrm{C} 6$ toward alkaline earth salts is also important in term of practical applications. Fig. 5 displays the variation of the calculated $\Delta G$ values for $M X_{2} L$ complexes in different solvent types. One factor that determines the solvent characteristic is the polarity (dielectric constants). The dielectric constant reduce in the order methanol $(32.63)>$ ethanol $(24.55)>$ THF (7.58) > benzene (2.24). It can be seen from Fig. 5 that the higher the solvent dielectric constant, the higher the calculated $\Delta G$ values. The $\Delta G$ values in methanol is higher than that of ethanol for $\mathrm{M}\left(\mathrm{NO}_{3}\right)_{2} \mathrm{~L}$ while this trend is reversed for $\mathrm{MCl}_{2} \mathrm{~L}$ complexes. It clearly shows that 

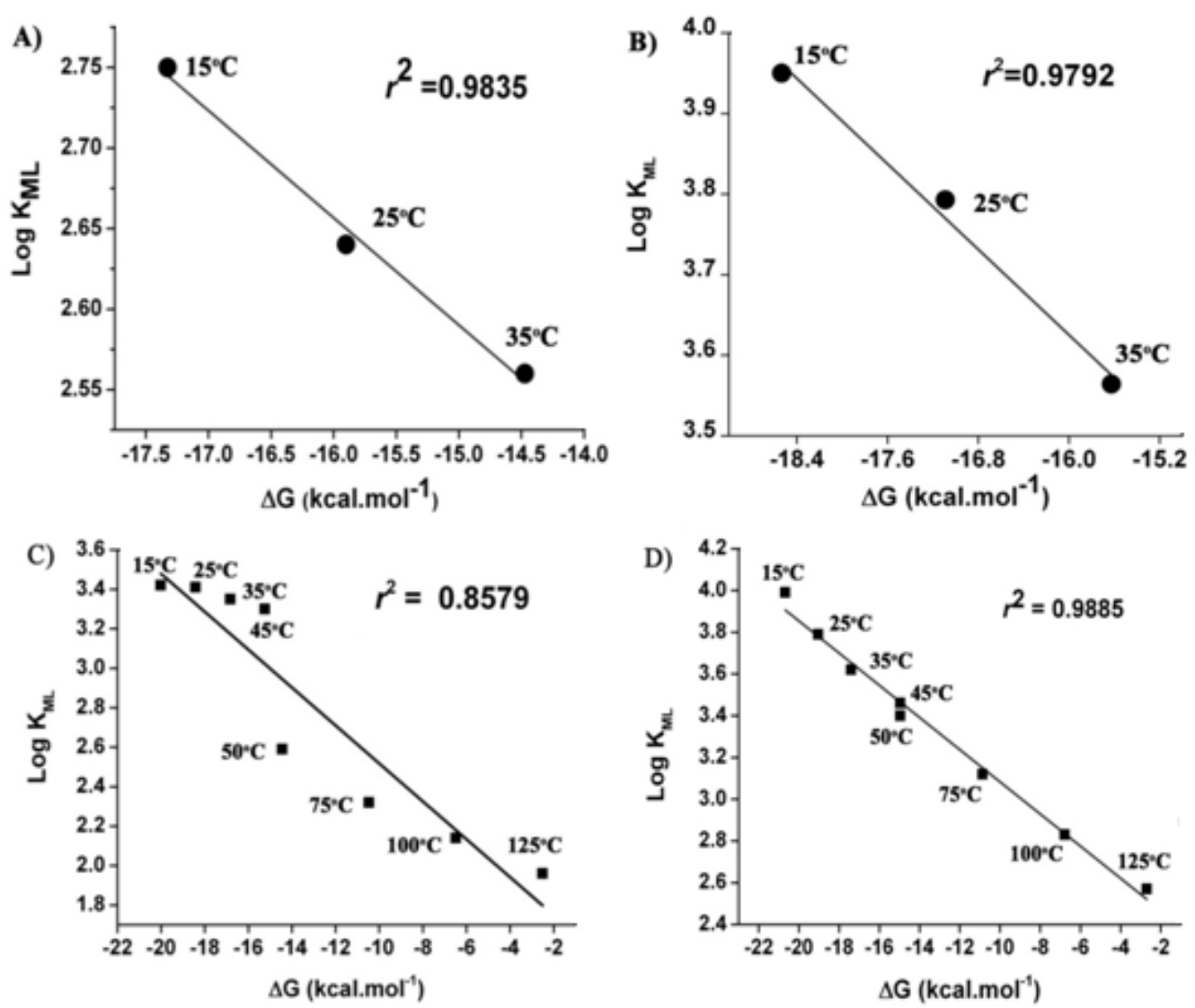

Fig 6. The correlation between calculated $\Delta G$ and the experimental log $K_{M L}$ values at different temperatures, ref [29-31]. A) $\left.\left.\left.\mathrm{SrCl}_{2} \mathrm{~L}, \mathrm{~B}\right) \mathrm{BaCl}_{2} \mathrm{~L}, \mathrm{C}\right) \mathrm{Sr}\left(\mathrm{NO}_{3}\right)_{2} \mathrm{~L}, \mathrm{D}\right) \mathrm{Ba}\left(\mathrm{NO}_{3}\right)_{2} \mathrm{~L}$ complexes

the preference solvent is also determined by the types of counterions. Generally, the complexes of $L$ and alkaline earth salts favor polar solvents. When $\mathrm{Cl}^{-}$acts as counterion, ethanol is a better choice of solvent. The opposite trend is shown when $\mathrm{NO}_{3}{ }^{-}$acts as counterion in which methanol is a better solvent. For non polar solvents (e.g. THF and benzene), the $\Delta G$ trend shows no different for both counterions. Interestingly, it is found that benzene gives positive values of $\Delta G$ (thermodynamically endothermic). The possible reason for this trend is the less solubility of metal salts and $L$ in benzene leads to less ion-dipole interaction in benzene environment.

\section{The Effect of Temperatures}

In addition to counterions and solvent types, the temperature also plays role in the extraction processes, thus, it is important to include the effect of temperatures in this study. To study the role of temperature, the correlation between the calculated $\Delta G$ and the experimental stability constant $\left(\log \mathrm{K}_{\mathrm{ML}}\right)$ for $\mathrm{BaX}_{2} \mathrm{~L}$ complexes at different temperatures have been determined and displayed in Fig. 6.

The correlation between calculated $\Delta G$ and log $\mathrm{K}_{\mathrm{ML}}$ at different temperatures shows a linear trend where their correlation is based on simple equation $\Delta G=-R T($ In $\mathrm{K})$. The calculated $\Delta \mathrm{G}$ and $\log \mathrm{K}_{\mathrm{ML}}$ at different temperatures show linier trends, $r^{2}=0.9835$ and $r^{2}=0.9792$ for $\mathrm{SrCl}_{2} \mathrm{~L}$ and $\mathrm{BaCl}_{2} \mathrm{~L}$ respectively. The same linier trend also can be seen for $\mathrm{Sr}\left(\mathrm{NO}_{3}\right)_{2} \mathrm{~L}$ and $\mathrm{Ba}\left(\mathrm{NO}_{3}\right)_{2} \mathrm{~L}$ complexes with $r^{2}=0.8579$ and $r^{2}=0.9885$, respectively. Close observation from Figure 6 shows that the experimental binding constant log $\mathrm{K}_{\mathrm{ML}}$ of $\mathrm{Ba}\left(\mathrm{NO}_{3}\right)_{2} \mathrm{~L}$ complex in water at $25^{\circ} \mathrm{C}$ is $3.79 \pm 0.05$ and reduced to $2.57 \pm 0.01$ at $125{ }^{\circ} \mathrm{C}$. The calculated $\Delta \mathrm{G}$ values also follow this trend where at $25{ }^{\circ} \mathrm{C}$ where the calculated $\Delta G$ is -19.01 kcal.mol ${ }^{-1}$ and at $125{ }^{\circ} \mathrm{C}$ reduces to $-2.12 \mathrm{kcal}^{\mathrm{mol}} \mathrm{m}^{-1}$. Based on this result, the effect of temperatures can be summarized as follows: 1) the temperature changes the strength of complex interaction but does not change the selectivity order; 2) low temperature is necessary in order to gain better interaction strength between alkaline earth salts and crown ether. 


\section{CONCLUSION}

The present work reports the various structural, energetic and thermodynamical parameters for alkaline earth 18-crown-6 (L) complexes at DFT/B3LYP level of theory in gas as well as in solvent phase. The emphasize of this work is to study the role of counterions, extraction temperatures and solvent types on the extraction selectivity of $\mathrm{L}$ toward $\mathrm{CaX}_{2}, \mathrm{SrX}_{2}$ and $\mathrm{BaX}_{2}\left(X=\mathrm{Cl}^{-}\right.$and $\left.\mathrm{NO}_{3}^{-}\right)$. Minimum energy structure confirms that $\mathrm{Cl}^{-}$binds in monodentate binding mode where $\mathrm{NO}_{3}{ }^{-}$binds in bidentate binding mode. It is found that the order of interaction energies and thermodynamics parameters in gas phase are $\mathrm{CaCl}_{2} \mathrm{~L}>$ $\mathrm{SrCl}_{2} \mathrm{~L}>\mathrm{Sr}\left(\mathrm{NO}_{3}\right)_{2} \mathrm{~L}>\mathrm{Ca}\left(\mathrm{NO}_{3}\right)_{2} \mathrm{~L}>\mathrm{BaCl}_{2} \mathrm{~L}>\mathrm{Ba}\left(\mathrm{NO}_{3}\right)_{2} \mathrm{~L}$. It clearly shows that $\mathrm{Cl}^{-}$is the preference counterion than $\mathrm{NO}_{3}{ }^{-}$counterion in which $\mathrm{Cl}^{-}$produces higher interaction energies and thermodynamics parameters. This trend also confirms by second order interaction energies, energy gab HOMO-LUMO, charge transfer and electrostatic potential maps of the studied complexes. The presence of solvents weaken the interaction between metal salts and $\mathrm{L}$. It reverses the gas phase binding selectivity trends of $\mathrm{L}$ : $\mathrm{Ba}\left(\mathrm{NO}_{3}\right)_{2} \mathrm{~L}>\mathrm{BaCl}_{2} \mathrm{~L}>$ $\mathrm{Sr}\left(\mathrm{NO}_{3}\right)_{2} \mathrm{~L}>\mathrm{SrCl}_{2} \mathrm{~L}>\mathrm{Ca}\left(\mathrm{NO}_{3}\right)_{2} \mathrm{~L}>\mathrm{CaCl}_{2} \mathrm{~L}$. It also reverses the preferential counterion where $\mathrm{NO}_{3}{ }^{-}$ contributes to higher interaction energies and thermodynamics parameters. The calculated $\Delta G$ values in polar solvent (e.g. methanol and ethanol) are higher in comparison to non polar (low dielectric constant) solvents (e.g. THF and benzene). The $\mathrm{MCl}_{2} \mathrm{~L}$ complexes prefer ethanol than methanol as the solvent while for $\mathrm{M}\left(\mathrm{NO}_{3}\right)_{2} \mathrm{~L}$ complexes prefer methanol. Benzene is less favorable for all complexes due to the endothermic values of the calculated $\Delta G$. In different temperatures, the higher the temperatures the lower the calculated $\Delta G$ values so that low temperature is necessary in order to have a successful extraction of alkaline earth salts by crown ether. The present study would have a significant contribution for optimizing the extraction conditions in term of the choice of counterions, solvent types and optimum extraction temperatures.

\section{REFERENCES}

1. Pedersen, C.J., 1967, J. Am. Chem. Soc., 89 (26), 7017-7036.

2. Pedersen, C.J., 1967, J. Am. Chem. Soc., 89 (10), 2495-2496.

3. Vögtle, F., and Weber E, 1989, Crown Ethers and Analogs, John Wiley \& Sons: New York.

4. Jensen, M.P., Dzielawa, J.A., Ricket, P., and Dietz, M.L., 2002, J. Am. Chem. Soc., 124 (36), 10664-10665.
5. Ansarifard, M., and Rounaghi, G.H., 2005, J. Inclusion Phenom. Macrocyclic Chem., 52 (1-2), 39-44.

6. Rounaghi, G., Eshaghi, Z., and Ghiamati, E., 1997, Talanta, 44 (2), 275-282.

7. Rounaghi, G.H., Mohajeri, M., Tarahomi, S., and Rahmanian, R., 2010, J. Solution Chem., 40 (3), 377-389.

8. Rounaghi, G.H., Soleamani, A., and Sanavi, K.R., 2007, J. Inclusion Phenom. Macrocyclic Chem., 58 (1-2), 43-50.

9. Glendening, E.D., and Feller, D., 1996, J. Am. Chem. Soc., 118 (25), 6052-6059.

10. Choi, C.M., Lee, J.H., Choi, Y.H., Kim, H.J., Kim, N.J., and Heo, J., 2010, J. Phys. Chem. A, 114 (42), 11167-11174.

11. Boda, A., Ali, S.M., Shenoi, M.R.K., Rao, H., and Ghosh, S.K., 2011, J. Mol. Model. 17 (5), 1091-1108.

12. Hadisaputra, S., Canaval, L.R., Pranowo, H.D., and Armunanto, R., 2014, Monatsh. Chem., 145 (5), 737-745.

13. Yamin, Pranowo, H.D., and Armunanto, R., 2010, Indo. J. Chem., 10 (1), 106-109.

14. Yamin, Pranowo, H.D., and Armunanto, R., 2012, Indo. J. Chem., 12 (2), 135-140.

15. Diao, K.S., Bai, L.J., and Wang, H.J., 2011, Comput. Theor. Chem., 964 (1-3), 18-24.

16. Xia, Y., Wang, X., Zhang, Y., Luo, B., and Liu, Y., 2012, J. Mol. Model., 18 (6), 2291-2299.

17. Heo, J., 2012, Bull. Korean. Chem. Soc., 33 (8), 2669-2674.

18. Boda, A., Ali, S.M., Shenoi, M.R.K., Rao, H., and Ghosh, S.K., 2012, J. Mol. Model., 18 (8), 3507-3522.

19. Hadisaputra, S., Pranowo, H.D., and Armunanto, R., 2012, Indo. J. Chem., 12 (3), 207-216.

20. Frisch, M.J., Trucks, G.W., Schlegel, H.B., Scuseria, G.E., Robb, M.A., Cheeseman, J.R., Montgomery, J.A.Jr., Vreven, T., Kudin, K.N., Burant, J.C., Millam, J.M., lyengar, S.S., Tomasi, J., Barone, V., Mennucci, B., Cossi, M., Scalmani, G., Rega, N., Petersson, G.A., Nakatsuji, H., Hada, M., Ehara, M., Toyota, K., Fukuda, R., Hasegawa, J., Ishida, M., Nakajima, T., Honda, Y., Kitao, O., Nakai, H., Klene, M., Li, X., Knox, J.E., Hratchian, H.P., Cross, J.B., Adamo, C., Jaramillo, J., Gomperts, R., Stratmann, R.E., Yazyev, O., Austin, A.J., Cammi, R., Pomelli, C., Ochterski, J.W., Ayala, P.Y., Morokuma, K., Voth, G.A., Salvador, P., Dannenberg, J.J., Zakrzewski, V.G., Dapprich, S., Daniels, A.D., Strain, M.C., Farkas, O., Malick, D.K., Rabuck, A.D., Raghavachari, K., Foresman, J.B., Ortiz, J.V., Cui, Q., Baboul, A.G., Clifford, S., Cioslowski, J., Stefanov, B.B., Liu, G., Liashenko, 
A., Piskorz, P., Komaromi, I., Martin, R.L., Fox, D.J., Keith, T., Al-Laham, M.A., Peng, C.Y., Nanayakkara, A., Challacombe, M., Gill, P.M.W., Johnson, B., Chen, W., Wong, M.W., Gonzalez, C., and Pople, J.A., 2003, Gaussian 2003W rev. B.05., Gaussian Inc., Pittsburgh.

21. Boys, S.F., and Bernardi, F., 1970, Mol. Phys., 19 (4), 533-566.

22. Shamov, G.A., Schreckenbach, G., Martin, R.L., and Hay, P.J., 2008, Inorg. Chem., 47 (5), 1465-1475.

23. Thompson, J.D., Cramer, C.J., and Truhlar. D.G., 2003, J. Chem. Phys., 119 (3), 1661-1670.

24. Pratt, L.M., Tran, P.T.T., Nguyen, N.V., and Ramachandran, B., 2009, Bull. Chem. Soc. Jpn., 82 (9), 1107-1125.

25. Polyanskaya, T.M, Rozhdestvenskaya, I.V., and Nikulina, L.D. 1994, J. Struct. Chem., 35 (3), 324-333.
26. Dunitz, J.D., and Seisler, P., 1974, Acta Crystallogr., Sect. B: Struct. Sci., 30 (11), 2739-2741.

27. Maverick, E., Seiler, P., Schweizer, W.B., and Dunitz, J.D., 1980, Acta Crystallogr., Sect. B: Struct. Sci., 36 (3), 615-620.

28. Hehre, W. J., 2003, A Guide to Molecular Mechanics and Quantum Chemical Calculations, Wavefunction, Inc., Irvine, CA.

29. Arnaud-Neu, F., Delgado, R., and Chaves, S., 2003, Pure Appl. Chem., 75 (1), 71-102.

30. Markova, N.V., and Vasiliev, V.P., 1995, J. Therm. Anal., 45 (4), 695-701.

31. Wang, P., Izatt, R.M., Gillespie, S.E., Oscarson, J.L., Zhang, X.X., Wang, C., and Lamb, J.D., 1995, J. Chem. Soc., Faraday Trans., 91 (23), 4207-4213. 